\title{
ASIA PACIFIC JOURNAL OF EDUCATORS AND EDUCATION
}

Volume 36, Number 2, 2021

https://doi.org/10.21315/apjee2021.36.2.15

Research Article:

\section{Online English Teacher Training during the COVID-19 Pandemic in the Thai Contexts}

\section{Kriengkrai Sakulprasertsri ${ }^{*}$, Supong Tangkiengsirisin', Supakorn Phoocharoensil', Monthon Kanokpermpoon ${ }^{2}$ and Sichon Koowuttayakorn'}

${ }^{1}$ Language Institute, Thammasat University, Rangsit Campus, 99, Moo 18 Paholyothin Rd. Klong Neung, Klong Luang Pathumthani, Bangkok 12120, Thailand

${ }^{2}$ Language Institute, Thammasat University, Tha Prachan Campus, 2, Prachan Road Phranakhorn, Bangkok 10200, Thailand

*Corresponding author: kriengkrai.s@litu.tu.ac.th; kriengkrai.cu@gmail.com

\begin{abstract}
During the disruptive coronavirus pandemic, English Language Teaching (ELT) teachers, among others, encountered dramatic changes and challenges regarding instruction, assessment, and research. Due to an abrupt shift from onsite to online modes, they urgently needed digital professional development to enhance their academic performance. A number of webinars were launched to provide information useful for ELT practices. This mixed-methods study was aimed at investigating how three webinars (on online toolkits, research publication, and action research) organised by a language institute at a Thai university were perceived in terms of satisfaction and usefulness. Forty-eight participants responded to an online questionnaire, and five of the participants attended online focus-group interviews. Both quantitative and qualitative data revealed that the participants had a high level of satisfaction towards and usefulness of the webinars because of the content, the speakers, as well as the format. Some of them, however, expressed their interest to engage more deeply with the webinars and the speakers through other audience engagement activities than a simple Q\&A session in the end. These findings provide insights into how the language institute will be able to organize webinars more effectively for ELT professional development by increasing the level of audience engagement throughout the session to better simulate the face-to-face interaction found in on-site seminars.
\end{abstract}

Keywords: ELT professional development, ELT webinar, teaching English during COVID-19, teacher training, satisfaction and usefulness

To cite this article: Sakulprasertsri, K., Tangkiengsirisin, S., Phoocharoensil, S., Kanokpermpoon, M., \& Koowuttayakorn, S. (2021). Online English teacher training during the COVID-19 pandemic in the Thai contexts. Asia Pacific Journal of Educators and Education, 36(2), 299-316. https://doi.org/10.21315/apjee2021.36.2.15

(C) Penerbit Universiti Sains Malaysia, 2021. This work is licensed under the terms of the Creative Commons Attribution (CC BY) (http://creativecommons.org/licenses/by/4.0/). 


\section{INTRODUCTION}

Coronavirus disease (COVID-19) has been impacting life since late 2019. As of early August 2021, the deadly virus has claimed over 4,200,000 lives, with over 190 million confirmed cases across the world (World Health Organisation). Countries around the globe, suffering from the spread of COVID-19, have implemented various measures to prevent the introduction and spread of COVID-19 in schools and into the community. To protect the health and safety of school personnel and students, school closures have proven to be one practical solution (Watson Todd, 2020). Shifting from the face-to-face lessons to an entirely virtual model obviously poses unforeseen problems and challenges for those involved, particularly teachers, students, and parents (Sepulveda-Escobar \& Morrisson, 2020). Just like those in other countries coping with the adaptation caused by a change in teaching platforms, educators in Thailand find adopting online teaching, i.e., a virtual classroom with which both they and their students are hardly familiar, very challenging (Jansem, 2021; Kanchai, 2021; Thumvichit, 2021).

It is clear that online instruction requires tremendous digital skills on the part of teachers (Yandell, 2020). Not only must educators acquire digital literacy but they are also required to continue acquiring skills in terms of research knowledge and research result dissemination. This is true even when attending on-site seminars for professional development is impossible. One of the best platforms allowing for continuing online teacher professional development (OTPD) is the webinar, which does not require meeting at a predefined time or space, thus offering a number of advantages (e.g. Compen et al., 2021; Ebner \& Gegenfurtner, 2019; Gegenfurtner \& Ebner, 2019; Gupta \& Sengupta, 2021). Despite existing studies on the use of webinars for teacher training, there appears very limited research focusing on ELT practitioners' perceptions of and satisfaction towards the usefulness of webinars which they have attended. It was for this reason that the present study was conducted to examine the extent to which ELT teachers in the Thai context found three webinars on online toolkits (Webinar 1), research publication (Webinar 2), and action research for English teachers (Webinar 3) useful and satisfactory for their professional development. In the present study, the usefulness and satisfaction of different webinars were studied to answer the following research questions:

1. To what extent did the Thai EFL practitioners find the three webinars satisfactory and useful?

2. In what way were the webinars useful for their professional practices in terms of pedagogy and research?

\section{Thai Education During the Pandemic: Shifting from On-Site to Online ELT}

The first strike of COVID-19 in the Kingdom of Thailand was officially noticed in March 2020, which finally resulted in lockdown and curfew measures in many parts of the country. The pandemic has had a huge impact on a great number of sectors, including education. In response to the disease-control measures implemented by the Ministry of Education $(\mathrm{MoE})$, in charge of kindergarten, primary, and secondary education, and the Ministry of 
Higher Education, Science, Research and Innovation (MHESI), responsible for tertiary education of the nation, schools and universities have promptly shifted their platform of instruction from on-site to online classrooms (Jansem, 2021). Such an abrupt conversion to the online teaching mode has been a challenge to students, teachers, and troubled parents looking after their children while learning online (Yi \& Jang, 2020).

Not only do students have to exert a great deal of effort in their online study, but teachers also need to make substantial adjustments for survival in their online instruction. In other words, emergency remote teaching has proven burdensome for several teachers in Thailand whose digital literacy is limited. Somsathan and Sanjaiprom (2021) determined some major factors impeding Thai teachers' success in conducting online instruction. As a consequence of the sudden shift to online education, teachers find themselves lacking in proper training, often incapable of utilizing digital toolkits for their online classrooms. As institutions invest in different online platforms for distance learning and teaching such as Teams, Zoom, Google Meet, or Webex, intensive teacher training is mandatory. Some part-time teachers who conduct online instruction for different schools/universities need to furthermore familiarise themselves with the assigned platforms, which means additional time and effort are expected.

A number of changes in the way English is introduced to students in Thailand have arisen from school/university closures as stated earlier. To successfully conduct distance classes during the pandemic, teachers and students are required to possess an adequate level of digital literacy (Jansem, 2021; Yi \& Jang, 2020). Due to the fact that traditional classrooms have been replaced by virtual ones, teacher and student digital skill development plays a crucial role in English as a Foreign Language (EFL) education (Yandell, 2020). In accordance with the dramatic change from face-to-face to online classrooms, EFL teachers' digital literacy development is required for distance education (Yandell, 2020).

When online instruction became the only choice available in Thailand in March 2020 due to the epidemic, ELT practitioners at every level had to reconfigure classes and conduct emergency remote teaching. Similar to what has been done in the early times of virtual classrooms in many other virus-stricken countries (e.g., Yi \& Jang, 2020), some EFL online classrooms in Thailand were conducted using pre-recorded video lessons as opposed to real-time instruction. As teachers acclimatize to online instruction, virtual classrooms became part of their new-normal life in their teaching career (Jansem, 2021; Watson Todd, 2020).

\section{Essential Skills for Online EFL Practitioners and Researchers}

As a consequence of the COVID-19 pandemic, teachers in Thailand need considerable adjustments for efficiency in online instruction. Teachers are expected to improve their digital literacy to the highest degree in response to the online instruction. Studies have shown that English teachers in Thailand have been faced with considerable technological difficulties in conducting online classes (e.g., Kanchai, 2021; Watson Todd, 2020). 
Watson Todd (2020) explored common online-teaching tools and problems confronting 52 English lecturers at a reputable Thai university. The results revealed that the most serious problem in the sudden shift from traditional to online instruction was the time the teachers spent in online lesson preparation. These problems decreased as more teachers' online-teaching experience increased over the semester. Some teachers admitted that they sought technical advice and help from students, fellow teachers and information technology or IT unit staff.

EFL online instruction quality is largely attributed to the application of more advanced technology and "simply repackaging the same content and activities from the classroom to online is not enough". Kanchai (2021), drawing data from in-depth interviews, shows that Thai EFL university lecturers developed their digital literacy through self-study at the beginning of the COVID-19 pandemic. Most of them encountered similar problems as they did not have time to adapt themselves to become adept at online teaching. Abruptly shifting from on-site classrooms to online ones, the participants found videos on YouTube useful for the development and delivery of their online lessons. In line with Watson Todd (2020), Kanchai found Thai EFL lecturers relied heavily upon advice from their colleagues for better understanding of the online VDO tutorial clips. Thai teachers, it is also worth noting, seek assistance from students, who are more digitally skillful. As ELT teachers' digital literacy is of paramount importance during the pandemic, the first webinar under investigation was on how teachers can utilise online toolkits for instruction.

In addition to the digital skills necessary for online instruction, teachers also have to keep abreast of current research trends and conduct their own research in the contexts of ELT classrooms. It is recommended that teachers do classroom-based research or action research, which "...is more relevant and doable for teachers as it takes considerably less time to carry out” (Renandya, 2016). Action research is important for two main reasons. First, it enables teachers to identify key factors affecting language learning in their classrooms so that teachers will be able to enhance their overall teaching quality. Second, reading the relevant literature, teachers doing action research will become more familiar with the theoretical and practical aspects of the topic (Burns, 2009; Renandya, 2016). Studies have demonstrated that action research improves teachers' instruction and students' knowledge in different areas of ELT, e.g., vocabulary (e.g., Kruawong \& Soontornwipast, 2021), reading (e.g., Manowong, 2017), instructional media (Wongsothorn et al., 2019), teachers' professional development (e.g., Jumpakate et al., 2021), and learner autonomy (e.g., Pichailuck \& Luksaneeyanawin, 2017).

What follows teachers' classroom-based research is dissemination of their findings to the public. One possible way to achieve this goal is to have a good understanding of publishing research articles in well-known international journals. As Lee (2014) points out, teachers and lecturers are required to have their research findings publicly known for several reasons, e.g., to share research results with others in the same discipline, to gain membership of the academic community, to ensure job security and career advancement, 
to derive satisfaction from doing challenging tasks, and so on. It is noteworthy that graduate students and early-career researchers are often times unaware of the danger of publishing in predatory journals, which charge a high fee for publication and accept a manuscript without a rigorous peer review process (Renandya, 2014). The number of such fake or questionable journals has been rising due to the ease of digital publication (Paltridge, 2020). Yeo et al., (2021) suggest that researchers avoid falling prey to these profit-oriented journals by publishing in a mainstream journal, indexed in worldrenowned trustworthy databases, e.g., Web of Science (WOS) or SCOPUS. Among other practical tips of increasing the chances of manuscript acceptance are carefully studying and strictly adhering to the author/submission guidelines, choosing the right journal whose aim and scope best fit the manuscript content, observing ethical issues regarding researching and publishing, and so on. As the knowledge of action research and publication is crucially important for teachers at the times of online teaching, the other two webinars conducted in the current study address both topics.

\section{Webinars and Professional Development}

Given the abrupt shift from in-class to online teaching during the COVID-19 pandemic, webinars have become a digital learning environment for educators to improve students' learning (Ebner \& Gegenfurtner, 2019; Gupta \& Sengupta, 2021; Gegenfurtner \& Ebner, 2019) and teachers' digital professional development (Compen et al., 2021). According to Nadama et al. (2019), the utility of webinars was highly perceived by medical students in the UK in terms of learning support and usefulness. The participants reported in the post webinar questionnaires that they could gain more medical knowledge from the webinars, and that webinar learning was efficient in terms of flexibility and time-and-money effectiveness.

A similar result was also reported by Gegenfurtner and Ebner (2019). In their systematic review and meta-analysis, it was found that learning through webinars in higher education was effective, yet the results revealed greater preference towards single webinars than repeated ones. They further reported that webinars provided more flexibility and cost effectiveness for webinar participants. A further study was conducted to compare the effectiveness and satisfaction among webinars, asynchronous online environments, and face-to-face learning contexts (Ebner \& Gegenfurtner, 2019). They found that webinars resulted in more effective learning than asynchronous online mode. However, given effective learning results, the average satisfaction level was significantly lower than that of face-to-face learning. This means that, at the expense of face-to-face learning during the COVID-19 pandemic, learning through webinars can still take place, but the satisfaction level might be at risk.

In terms of using webinars for professional development, Compen et al. (2021) argued that, for effective webinar learning, teacher participants should be engaged with the content and that assistance and interactive questions were available during webinar series. This means that, given the availability of webinars, effective learning takes place when the 
participants feel they are engaged with the webinars. This can be achieved by increasing the interaction between attendees and speakers through participation engagement tools such as online polls and discussion boards (Gegenfurtner et al., 2020).

At this point in this discussion, it can be argued that webinars have become a new normal learning platform for online teachers' professional development. As a result, obtaining direct feedback and recommendations on webinar delivery is crucial for designing, improving, and evaluating the effectiveness of the webinars (Gegenfurtner et al., 2020). At a language institute in a Thai university, webinars in ELT have been initiated and conducted in response to the required online teachers' professional development during the COVID-19 pandemic. However, whether these webinars were useful or satisfactory to the audiences is still a question. The findings of this study may shed light on the design, development and implementation of future webinars that are more effective and better meet the needs of Thai ELT teachers and researchers in this digital era.

\section{METHODOLOGY}

To respond to the research questions, the present project employed a mixed-methods approach combining both quantitative and qualitative analyses. The quantitative data were first obtained from a questionnaire, and the qualitative data collected from a focus-group interview were then used to support the questionnaire data for the purpose of triangulation. In particular, all data were collected to investigate the usefulness and satisfaction of three webinars offered by a language institute in a Thai university from June, 2020 to May, 2021. These three webinars concerned online toolkits (Webinar 1), research publication (Webinar 2), and action research for English teachers (Webinar 3), respectively. Webinar 1 was designed to train EFL teachers on how to use available technology and techniques for their virtual classrooms, such as light and settings, widelyused apps, and the use of social media for project-based learning. Webinar 2 dealt with practical tips for publishing in peer-reviewed international journals and top-ten reasons why manuscripts are often rejected, while Webinar 3 familiarised EFL teachers with action research framework and how it could be applied to online classroom-based research. These webinars were conducted live through the Zoom platform and recorded for further reference on the language institute's YouTube Channel. The three webinars were selected for teacher professional development related to technological pedagogy (Kanchai, 2021; Watson Todd, 2020), classroom-based action research (Jumpakate et al., 2021; Renandya, 2016), and research publication (Lee, 2014; Renandya, 2014).

There were 100 local Thai EFL practitioners, including secondary school teachers, college and university lecturers, and research scholars in Thailand, who participated in all the three webinars. The participants of the present study were recruited from the audience based on the purposive sampling technique. The criteria for participant selection 
included 1) being an in-service ELT professional; and 2) having watched all the three webinars, live or through the recorded channel, resulting in 55 participants. An online questionnaire was distributed to these participants, and 48 respondents returned the form. It can be assumed that although the number of participants were small, they represented the local Thai teachers who were the focus of the present study. Five participants from the questionnaire-returned respondents were recruited for focus group interviews since they represented 10\% of the participants (Woodrow, 2014). Three participants were university lecturers and the other two were second school teachers. Their average ages were approximately 24-26 years old, and have been teaching in their institutions for at least 3 years.

The major research tools in the present study included an online questionnaire adapted from Gegenfurtner et al. (2020) and Nadama et al. (2019) and online focus group interviews. The 5-point Likert-scale online questionnaire consisted of 19 questions categorized into 9 questions on satisfaction and another 10 questions on usefulness, where scale 5 means 'totally agree' and scale 1 means 'totally disagree'. An open-ended question on further suggestions was also included. These 20 questions were regarded as representing the usefulness and satisfaction since they could be used to capture the participants' perceptions towards the two constructs. To ensure the reliability and validity of the questionnaire, the questions were validated by three ELT experts in Thailand for the test of Index of Item Objective Congruence (IOC). The consistency result from the experts was $87 \%$. Some items were adjusted based on their suggestions prior to questionnaire distribution. In terms of the focus group interviews, five participants were selected to expand their views on the usefulness and satisfaction of the three webinars based on 4-5 questions. This is to ensure that all aspects of the questionnaire were covered and that data in the focus group could include more views in addition to those explored in the questionnaire.

The responses collected from the online questionnaires were descriptively analysed using means and standard deviations to compare perceptions of the usefulness and satisfaction of the three webinars in graphic representations. Since the number of participants was small, the focus group interviews were additionally used to gather more information. Data from the interviews were transcribed, analysed, and validated by two qualitative research experts using the concept-driven thematic content analysis regarding webinar content, satisfaction, and usefulness. The interview data were then combined with the questionnaire data to answer the research questions.

\section{RESULTS}

In the present study, most of the participants were college or university lecturers (26\%) who have worked for approximately 0-5 years $(43.8 \%)$, and had some degree of experience in internet technology (85.4\%). Most of them were female (26\%) between 26-30 years old (26\%). 
Regarding the findings, junior in-service university lecturers who were competent users of internet technology were the major audience of the language institute webinars. Information regarding their perceptions towards the satisfaction and usefulness of the three webinars will be discussed.

\section{The Satisfaction and Usefulness towards Three Webinars}

In Table 1, means and standard derivations of all the three webinars in terms of the two constructs, i.e., satisfaction and usefulness, are presented to answer research question 1 regarding the participants' perceptions towards the three webinars.

Table 1. Means and Standard Deviations of Satisfaction and Usefulness

\begin{tabular}{|c|c|c|c|c|c|c|}
\hline \multirow{2}{*}{$\begin{array}{l}\text { Satisfaction and usefulness of webinars } \\
(n=48)\end{array}$} & \multicolumn{2}{|c|}{ Webinar $1^{*}$} & \multicolumn{2}{|c|}{ Webinar $2^{* *}$} & \multicolumn{2}{|c|}{ Webinar $3^{* * * *}$} \\
\hline & M & $\mathrm{SD}$ & M & $\mathrm{SD}$ & M & $\mathrm{SD}$ \\
\hline \multicolumn{7}{|l|}{ SATISFACTION } \\
\hline I am satisfied with this webinar. & 4.54 & 0.58 & 4.58 & 0.58 & 4.48 & 0.65 \\
\hline $\begin{array}{l}\text { This webinar is flexible and convenient during } \\
\text { COVID-19 pandemic. }\end{array}$ & 4.67 & 0.52 & 4.77 & 0.43 & 4.71 & 0.46 \\
\hline The content of this webinar is relevant to my career. & 4.60 & 0.74 & 4.65 & 0.60 & 4.63 & 0.61 \\
\hline $\begin{array}{l}\text { The pace and length of this webinar are } \\
\text { appropriate for the amount of content. }\end{array}$ & 4.27 & 0.74 & 4.40 & 0.74 & 4.46 & 0.59 \\
\hline $\begin{array}{l}\text { I will recommend others (e.g., your graduate } \\
\text { students, colleagues) to watch this webinar. }\end{array}$ & 4.46 & 0.80 & 4.58 & 0.65 & 4.60 & 0.58 \\
\hline $\begin{array}{l}\text { I am looking forward to participating in a } \\
\text { webinar similar to this one. }\end{array}$ & 4.54 & 0.82 & 4.54 & 0.65 & 4.48 & 0.62 \\
\hline I was engaged with this webinar. & 4.04 & 0.92 & 4.42 & 0.74 & 4.23 & 0.83 \\
\hline I enjoyed attending this webinar very much. & 4.19 & 0.89 & 4.44 & 0.77 & 4.40 & 0.74 \\
\hline $\begin{array}{l}\text { I would participate in future webinars based on } \\
\text { this experience. }\end{array}$ & 4.42 & 0.71 & 4.54 & 0.58 & 4.48 & 0.65 \\
\hline Average Satisfaction & 4.41 & 0.77 & 4.55 & 0.65 & 4.50 & 0.65 \\
\hline \multicolumn{7}{|l|}{ USEFULNESS } \\
\hline $\begin{array}{l}\text { This webinar helps me become more effective in } \\
\text { my teaching or research. }\end{array}$ & 4.31 & 0.85 & 4.56 & 0.62 & 4.54 & 0.58 \\
\hline $\begin{array}{l}\text { This webinar taught me something which I } \\
\text { consider valuable. }\end{array}$ & 4.48 & 0.88 & 4.69 & 0.51 & 4.58 & 0.58 \\
\hline $\begin{array}{l}\text { I have become more knowledgeable about the topic } \\
\text { after this webinar. }\end{array}$ & 4.40 & 0.77 & 4.63 & 0.57 & 4.60 & 0.57 \\
\hline $\begin{array}{l}\text { I am able to apply the knowledge learned in this } \\
\text { webinar to my actual teaching and/or research. }\end{array}$ & 4.27 & 0.92 & 4.54 & 0.62 & 4.52 & 0.58 \\
\hline $\begin{array}{l}\text { My interest in the topic has increased after this } \\
\text { webinar. }\end{array}$ & 4.17 & 0.88 & 4.56 & 0.68 & 4.54 & 0.68 \\
\hline
\end{tabular}


Table 1. (Continued)

\begin{tabular}{|c|c|c|c|c|c|c|}
\hline \multirow{2}{*}{$\begin{array}{l}\text { Satisfaction and usefulness of webinars } \\
(n=48)\end{array}$} & \multicolumn{2}{|c|}{ Webinar $1^{*}$} & \multicolumn{2}{|c|}{ Webinar $2^{* *}$} & \multicolumn{2}{|c|}{ Webinar $3^{\text {**** }}$} \\
\hline & $\mathrm{M}$ & $\mathrm{SD}$ & M & SD & $\mathrm{M}$ & SD \\
\hline This webinar is useful for my teaching or research. & 4.33 & 0.86 & 4.63 & 0.57 & 4.54 & 0.62 \\
\hline $\begin{array}{l}\text { This webinar is important for my professional } \\
\text { development. }\end{array}$ & 4.42 & 0.79 & 4.67 & 0.52 & 4.52 & 0.62 \\
\hline $\begin{array}{l}\text { This webinar could be of some value to my } \\
\text { teaching or research. }\end{array}$ & 4.40 & 0.82 & 4.63 & 0.57 & 4.58 & 0.61 \\
\hline $\begin{array}{l}\text { This webinar provides knowledge and updates my } \\
\text { skill. }\end{array}$ & 4.33 & 0.91 & 4.52 & 0.65 & 4.54 & 0.50 \\
\hline $\begin{array}{l}\text { I am interested in learning more about the topic } \\
\text { after this webinar. }\end{array}$ & 4.29 & 0.87 & 4.60 & 0.58 & 4.42 & 0.65 \\
\hline Average Usefulness & 4.34 & 0.77 & 4.60 & 0.49 & 4.54 & 0.51 \\
\hline
\end{tabular}

Notes: *Webinar 1: Online Toolkit for ELT Survival: Ideas from Social-distancing Teachers; **Webinar 2: Seizing Publication Opportunities in SCOPUS Journals \& Top 10 Reasons for Journal Rejection; ***Webinar 3: Demystifying Action Research for English Language Teachers

\section{Satisfaction}

In terms of satisfaction (see Figure 1), the participants perceived Webinars 1, 2 and 3 as '... flexible and convenient during the COVID-19 pandemic $(\mathrm{M}=4.67,4.77$, and 4.71, respectively). In the same vein, they regarded all the webinars' content as '... relevant to [their] career' $(M=4.60,4.63$, and 4.60, respectively). It can be argued that, during the COVID-19 pandemic, the webinars on online toolkits (Webinar 1), research publication (Webinar 2), and action research for ELT teachers (Webinar 3) were regarded as relevant to the participants' teaching profession. These webinars also helped increase the participants' level of satisfaction, especially considering it was flexible and convenient to participate in these webinars.

Regarding Webinars 1 and 3, it seems that the participants perceived themselves as least engaged with the webinars ( $M=4.04$ and 4.23 , respectively) as depicted in Figure 1. However, the high degree of scale, i.e., more than 4 , means that the participants still maintained their high level of satisfaction towards both webinars. This suggests that for future webinars, the organisers could consider participants' engagement. 
Kriengkrai Sakulprasertsri et al.

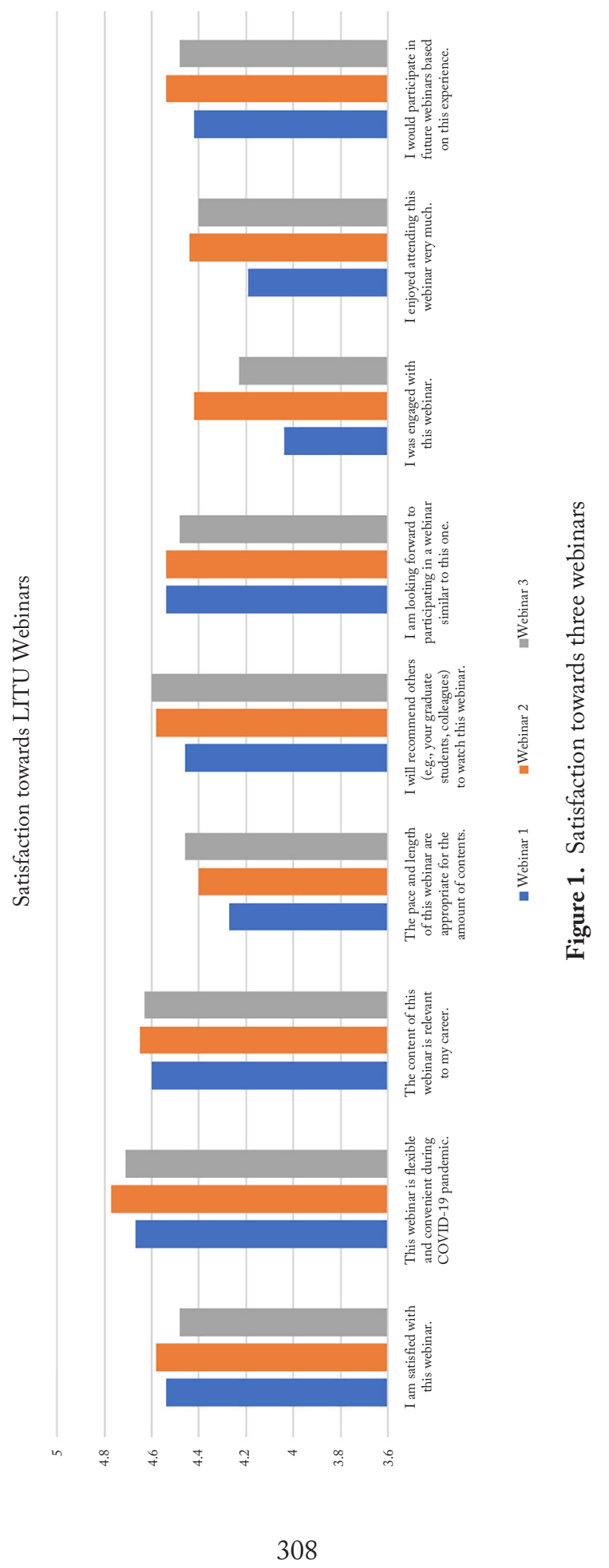




\section{Usefulness}

Regarding the usefulness of the webinars, it appears that, on average, Webinar 1, i.e., online toolkits, was comparatively perceived as the least useful among the three webinars, while Webinar 2, i.e., research publication, was regarded as the most useful (see Figure 2). It can be concluded that the content of each webinar, to some degree, entailed different patterns of perceptions towards webinars' usefulness. This is further explained below.

In Webinar 1, that is online toolkits for language teaching, the participants responded that 'this webinar taught [them] something which [they] consider valuable' as the most useful factor $(M=4.48)$, this pattern is similar to Webinar $2(M=4.69)$ on research publication. In a similar trend, both Webinars 1 and 2 were also perceived as promoting the participants' professional development $(\mathrm{M}=4.42$ and 4.67 , respectively). This means that the online toolkit webinar (Webinar 1) and the research publication webinar (Webinar 2) were highly regarded as useful in terms of valuable practice in ELT and promoting continuing professional development.

When it comes to Webinar 3, i.e., action research for ELT teachers, the participants responded favorably that "[they] have become more knowledgeable about the topic after this webinar' $(M=4.60)$. They further reported that this webinar 'taught [them] something which [they] consider valuable' $(M=4.58)$, especially in terms of '[their] teaching or research' $(\mathrm{M}=4.58)$. This means that the action research for ELT teacher webinar helped the participants enhance their knowledge and support their teaching and/or research.

After participating in the three webinars, the participants were satisfied in terms of flexibility, convenience, and relevance to their career, but had varying opinions in terms of the practical uses for professional development (Webinars 1 and 2) and gaining more knowledge for teaching and/or research (Webinar 3). 
Kriengkrai Sakulprasertsri et al.

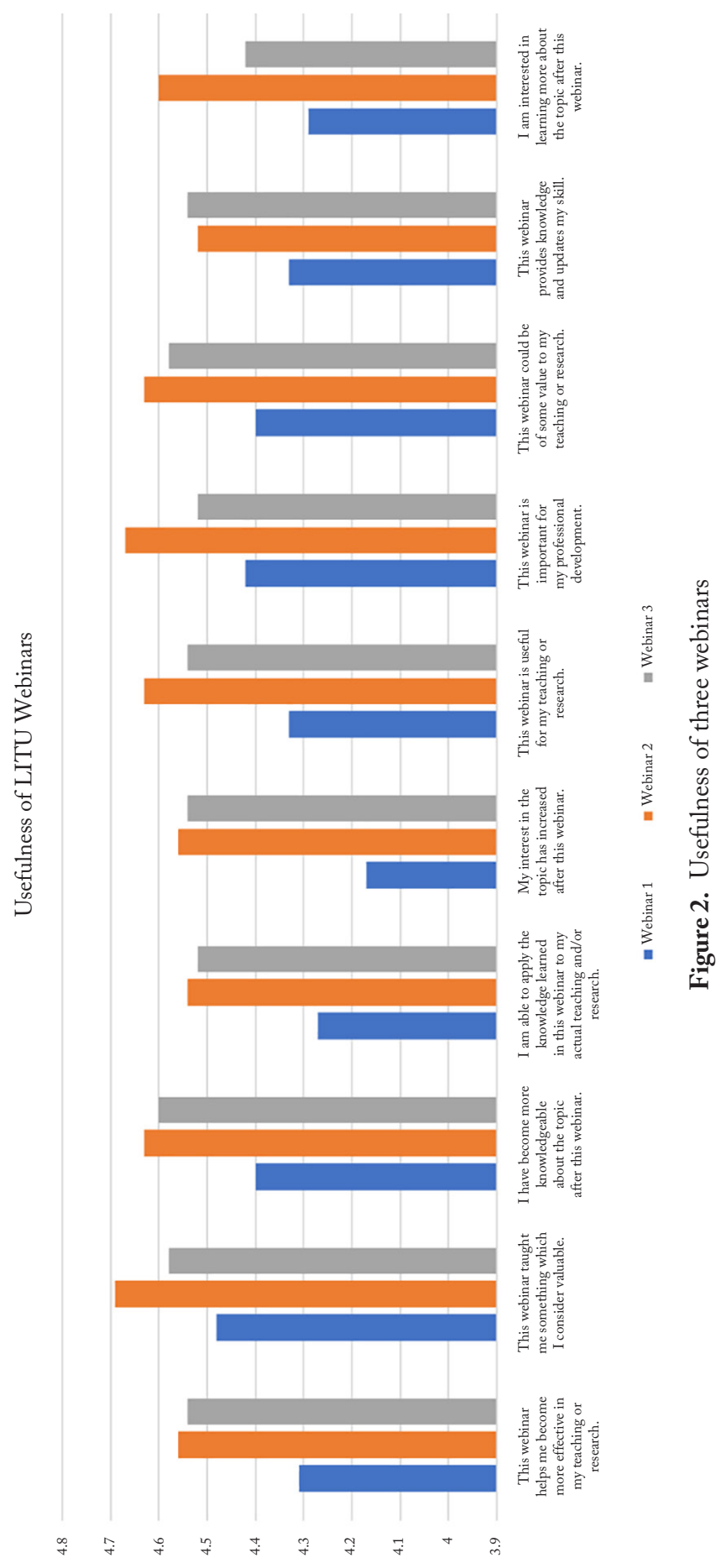




\section{RESULTS OF THE QUALITATIVE DATA}

To further explore the participants' satisfaction and perceived usefulness towards attending the three webinars, content analysis was employed to analyse the responses obtained from the open-ended questions in the questionnaire as well as the data from the focus group interviews.

\section{Usefulness}

The qualitative findings revealed that the participants believed all three webinars were useful to their career in both teaching and research perspectives. To begin with, many of the participants found that the webinars were successful in supplying them with awareness about available online teaching tools which can be used to promote students' motivation and engagement. This was especially true for the participants who attended the first webinar, which focused on sharing ideas and online toolkits for ELT. In addition, several participants reported that they were impressed with the knowledge about lighting and the use of gestures in online classrooms, which were aspects of teaching to which they did not previously pay attention.

Moreover, the participants also found the webinars useful in the aspects of research and publication as they gained knowledge in how to write good research articles and choose qualified journals for publication. Some participants also felt more confident in terms of writing and getting their articles published after being inspired by the speakers. This was shown in the comments such as: "As a reflective teacher, the webinar provided a systematic framework through which I can further improve my teaching and perhaps produce an academic article out of it." "I will use it as bible to accommodate the loopholes of my current research. In this way will give me confidence to publish my manuscript academically."; and "I would apply one of the tool kits for my academic research which is really helpful for recording students' voices." It can be seen from these responses that the webinars did not only enhance the participants' everyday teaching practices but also inspired them to conduct research.

\section{Satisfaction}

In regard to the participants' satisfaction, the findings showed that overall, the participants were satisfied with all three webinars in three aspects: the content; the speakers; and the webinar format. First of all, the participants found the content of the webinars valuable in providing resources and practical tips and techniques for enhancing teaching experiences and research practices. To elaborate, the participants expressed that they were impressed with the content on how to integrate different online tools and resources to engage students. This was expressed in the comments such as, "Considering my teaching philosophy and workplace context, I'd say the topic of using an online toolkit to promote student engagement was the most satisfactory"; and "I found using online toolkit the most satisfactory. This is because I can use it in my online English 
classes." Besides improving their teaching, the participants were also satisfied with the research-related content that provided them with useful information and step-by-step procedures for conducting action research and submitting articles for publication. One of the participants expressed: "Action Research Cycle is the most satisfactory. Although this part is not be applied in my teaching or research, I'll apply it in my professional. This part helps me to know how to deal the problems which not only in teaching but in my life."

Not only were the participants satisfied with the content of the webinars, but they were also pleased with the speakers as they were able to provide clear explanations, insightful knowledge, and personal anecdotes to make the attendees better understand the topics. Their appreciation of the speakers can be seen in the responses such as: "The speaker is very knowledgeable in the topic, so he made everything clear"; "I think all the speakers provided clear explanations and examples which helped the attendees understand more"; and "I found the speaker the most satisfactory. This is because the speaker has provided useful insights into how to publish research articles successfully". Therefore, it appears that the participants were impressed with the selection of the webinar speakers as they provided a diversity of expertise and were able to professionally share and exchange valuable knowledge on various topics.

Finally, the participants reported their satisfaction towards the format of the webinars as they offered flexibility and convenience in developing their professional and academic skills during the pandemic situation. Because these webinars were open to the public and available online, language educators and teachers from different parts of the world could attend the webinars at their own convenience. One response involving this issue is as follows: "I think it's convenient to attend the webinar. I can learn from anywhere. Actually, if I'm not available at the exact date and time when the webinar was held, I can still watch later on when I have time."

While the format of the webinars offered convenience and flexibility, some participants found them a bit less engaging because there was not enough time for discussion and questions since the Q\&A took place at the end. Moreover, the anytime-and-anywhere format of the webinars means that the attendees who watched the recorded rather than the live sessions would not be able to participate in the webinars or ask questions at all. Consequently, there was a comment from the focus group suggesting that they would like to see an extended workshop on how to write research articles. From this perspective, a hands-on workshop would allow the audience to be actively involved and instantly apply the knowledge gained to produce a meaningful written work. These kinds of activities could enhance interaction and collaboration during the webinars and yield more fruitful results for the attendees. 


\section{DISCUSSION}

This study revealed that webinars provided by the language institute at a Thai university satisfied the majority of participants in terms of flexibility and convenience. It could be argued that, in time of necessity which called for a swift reaction to a sudden university closure, webinars played a role in providing university lecturers with professional development (Gegenfurtner \& Ebner, 2019; Nadama et al., 2019). As reported in the focus group, attending online training through webinars provided opportunities for in-service teachers to enhance their knowledge in terms of cost-and-time effectiveness. This is especially true regarding the webinars on the topic of online toolkits and research publication. Since teachers did not have to spend time and money commuting to the seminar venue, chances to gain more knowledge from attending webinars were highly regarded by the audience.

In terms of acquiring knowledge from the webinars, different patterns of learning were found. According to Kanchai (2021) and Thumvichit (2021), teachers reported feeling reluctant in deciding what ways and which platforms to use in their online teaching, and Watson Tood (2020) even further advocated the application of more advanced technology for teachers' professional development. However, in the webinars of the present study, they were perceived as providing the audience with both information on which technical devices or tools to use as well as ways teachers could arrange their online learning environments and make use of available programs. This means the webinars enhanced teachers' knowledge along with expressing how collaborative teacher learning can be virtually conducted for more effective teaching.

In addition to the pedagogical context, the qualitative data revealed that teachers could gain advanced knowledge in terms of research publications and action research from live webinars provided by this language institute. This echoed what Gegenfurtner and Ebner (2019) found in terms of the effective use of single webinars for content learning. Based on the present study, each webinar was individually conducted for a specific time, and this might be a reason why the participants perceived some webinars as being more useful than the other. However, it seems that the two content webinars, i.e., research publication and action research, were perceived as similar to the existing webinars, but they could only be made possible if the speakers for webinars were admired and famous in their field.

Regarding speaker-audience interaction, Compen et al. (2021) and Wrenn (2015) advocated that online collaborative learning with a high level of interaction yields effective learning. In the case of the webinars provided by the language institute, however, the collaboration and interaction were limited because the webinars followed the conventional lecture format in which the talk and the discussion sections were separated. Thus, it was found that the participants perceived the webinars as least engaging. This was further explained in the focus-group interviews where the participants reported that they could only ask questions at the end of each webinar. Additionally, application of the knowledge gained from these webinars was minimalised because it lacked hands-on practice and 
personal level interaction. Therefore, it is suggested that, in future webinar organisation, a higher level of engagement and interaction be considered for an enhanced audience experience and more effective professional development.

\section{CONCLUSION AND RECOMMENDATION FOR FURTHER STUDIES}

As shown in the quantitative data, the participants of this study had a high level of satisfaction towards the three webinars. What was viewed as the most satisfactory concerned their flexibility and convenience as the participants could easily access the webinars at any time during the COVID-19 pandemic. In addition, they found that the three webinars were closely related and applicable to their teaching career. Webinar 2, with the topic of research publication, was considered the most useful, followed by Webinar 3, action research for ELT teachers, and Webinar 1, online toolkits for language teaching, respectively. The data drawn from the open-ended questions in the questionnaire and the focus group interviews provided support for the quantitative questions in that the participants reported to have considerably benefited from all the webinars, expressing their satisfaction with three main aspects, namely the content, the speakers, and the webinar format. It is highly recommended that future studies focus on participants' opinions regarding other ELT-related topics, e.g., teaching English to young learners, game-based teaching, etc. Participants can also be extended to other ELT practitioners, e.g., primary and kindergarten teachers (Thumvichit, 2021). As online instruction now seems to be the new-normal practice for ELT, future studies should also address the actual problems with which ELT instructors, as well as students, are confronted in their virtual learning and teaching (Kanchai, 2021; Watson Todd, 2020). This way, researchers can determine the real difficulties facing ELT teachers/students and find the best solutions in response to such online-education challenges (Yandell, 2020).

\section{REFERENCES}

Burns, A. (2009). Doing action research in English language teaching: A guide for practitioners. Routledge.

Compen, B., De Witte, K., \& Schelfhout, W. (2021). The impact of teacher engagement in an interactive webinar series on the effectiveness of financial literacy education. British Journal of Educational Technology, 52(1), 411-425. https://doi.org/10.1111/bjet.13013

Ebner, C., \& Gegenfurtner, A. (2019). Learning and satisfaction in webinar, online, and faceto-face instruction: a meta-analysis [Systematic Review]. Frontiers in Education, 4(92). https://doi.org/10.3389/feduc.2019.00092

Gegenfurtner, A., \& Ebner, C. (2019). Webinars in higher education and professional training: a meta-analysis and systematic review of randomized controlled trials. Educational Research Review, 28, 100293. https://doi.org/10.1016/j.edurev.2019.100293

Gegenfurtner, A., Zitt, A., \& Ebner, C. (2020). Evaluating webinar-based training: A mixed methods study of trainee reactions toward digital web conferencing. Training and Development, 24(1), 5-21. https://doi.org/10.1111/ijtd.12167 
Gupta, S. K., \& Sengupta, N. (2021). Webinar as the future educational tool in higher education of India: a survey-based study. Technology, Knowledge and Learning, 26, 1111-1130. https://doi.org/10.1007/s10758-021-09493-7

Jansem, A. (2021). The Feasibility of foreign language online instruction during the Covid-19 pandemic: A qualitative case study of instructors' and students' reflection. International Education Studies, 14(4), 93-102. https://doi.org/10.5539/ies.v14n4p93

Jumpakate, T., Wilang, J. D., \& Kong, C. (2021). Exploring the reflective typology of novice EFL teachers in a Thai university. International Journal of Evaluation and Research in Education, 10(2), 668-675. http://doi.org/10.11591/ijere.v10i2.21122

Kanchai, T. (2021). EFL teachers' ICT literacy acquisition to online instruction during COVID-19. LEARN Journal: Language Education and Acquisition Research Network, 14(2), 282-312. https://so04.tci-thaijo.org/index.php/LEARN/article/view/253270

Kruawong, T., \& Soontornwipast, K. (2021). The development of Thai EFL secondary school students' English science vocabulary knowledge through Science Vocabulary Crossword Puzzle (SVCP) Practices: Action research. Shanlax International Journal of Education, 9(4), 44-54. https://doi.org/10.34293/education.v9i4.4054

Lee, I. (2014). Publish or perish: The myth and reality of academic publishing. Language Teaching, 47(2), 250-261. https://doi.org/10.1017/S0261444811000504

Manowong, S. (2017). Incorporating online tools to promote English reading for EFL learners: An action research study. Pasaa Paritat Journal, 32, 98-124. https://www.culi.chula.ac.th/ publicationsonline/files/article2/Uz8VwjDfrZMon32902.pdf

Nadama, H. H., Tennyson, M., \& Khajuria, A. (2019). Evaluating the usefulness and utility of a webinar as a platform to educate students on a UK clinical academic programme. The Journal of the Royal College of Physicians of Edinburgh, 49(4), 317-322. https://doi.org/10.4997/ jrcpe.2019.415

Paltridge, B. (2020). Writing for academic journals in the digital era. RELC Journal, 51(1), 147-157. https://doi.org/10.1177/0033688219890359

Pichailuck, P., \& Luksaneeyanawin, S. (2017). Enhancing learner autonomy in rural young EFL learners through project-based learning: An action research. ABAC Journal, 37(2), 16-32. http://www.assumptionjournal.au.edu/index.php/abacjournal/article/view/3040

Renandya, W. A. (2014). Choosing the right international journal in TESOL and applied linguistics. English Language Teaching World Online: Voices from the Classroom, 6, 1-17. http://blog.nus.edu.sg/eltwo/2014/06/18/choosing-the-right-international-journal-in -tesol-and-appliedlinguistics/

Renandya, W. A. (2016). Teacher professional development: An interview with Dr. Willy A Renandya. PASAA, 51(1), 1-14. https:/www.culi.chula.ac.th/publicationsonline/files/ article/RMBR10or8iMon105646.pdf

Sepulveda-Escobar, P., \& Morrison, A. (2020). Online teaching placement during the COVID-19 pandemic in Chile: challenges and opportunities. European Journal of Teacher Education, 43(4), 587-607. https://doi.org/10.1080/02619768.2020.1820981

Somsathan, P., \& Sanjaiprom, S. (2021). Learning online preparedness during the COVID-19 pandemic in Thailand. Journal of MCU Peace Studies, 9(3), 884-894. https://so03.tci -thaijo.org/index.php/journal-peace/article/view/250814

Thumvichit, A. (2021). English language teaching in times of crisis: Teacher agency in response to the pandemic-forced online education. Teaching English with Technology, 21(2), 14-37. https://tewtjournal.org/volume-2021/volume-2021-issue-2/

Watson Todd, R. (2020). Teachers' perceptions of the shift from the classroom to online teaching. International Journal of TESOL Studies, 2(2), 4-16. https://doi.org/10.46451/ijts.2020.09.02 
Wongsothorn, A., Yordchim, S., Thitivesa, D., \& Pongsurapipa, S. (2019). Innovative use of English language teaching as an international language in graduate studies in Thai universities. LEARN Journal: Language Education and Acquisition Research Network, 12(2), 14-27. https://so04.tci-thaijo.org/index.php/LEARN/article/view/205048

Woodrow, L. (2014). Writing about quantitative research in applied linguistics. Palgrave Macmillan.

Wrenn, V. (2015). Effects of traditional and online instructional models on student achievement outcomes [Doctoral dissertation, Liberty University]. https://core.ac.uk/download/ pdf/58826829.pdf

Yandell, J. (2020). Learning under Lockdown: English teaching in the time of Covid-19. Changing English, 27(3), 262-269. https://doi.org/10.1080/1358684X.2020.1779029

Yeo, M. A., Renandya, W. A., \& Tangkiengsirisin, S. (2021). Re-envisioning academic publication: From "publish or perish" to "publish and flourish". RELC Journal, 1-10. https://doi.org/10.1177/0033688220979092

Yi, Y., \& Jang, J. (2020). Envisioning possibilities amid the COVID-19 pandemic: Implications from English language teaching in South Korea. TESOL Journal, 11(3), e00543. https://doi.org/10.1002/tesj.543 